\title{
Spanish Modernism in Context: Failed Heroism and Cross-Cultural Encounters in Pío Baroja and Joseph Conrad
}

\begin{abstract}
Over the last two decades, the recuperation of Spanish authors in the development of Modernist fiction in a pan-European context has gained increasing momentum among scholars. Extending the scope of these critical studies, my article presents a comparative analysis of cross-cultural encounters and ironic journeys of development in Joseph Conrad's Lord Jim (1900) and Pío Baroja's César o nada (1910). The study addresses three key strands: the question of direct influence; the thwarted search for self-definition set against the competing perceptions of multiple fictional observers; and finally the failed heroism of each protagonist which, I propose, symbolically references a scepticism towards European narratives of progress. The comparison of two authors (one Spanish; one Polish émigré) identifies resonant parallels between their fictional works and seeks to reframe Baroja and Conrad as literary counterparts across national borders in turn-of-the-century Spain and Britain.
\end{abstract}

Keywords: Modernism, subjectivity, irony, journey, heroism, Spain, Britain

Writing in Spain and Britain respectively at the turn of the twentieth century, Pío Baroja and Joseph Conrad were both transitional figures in the development of European Modernism. Like Conrad's Lord Jim (1900), Baroja's César o nada (1910) explores selfhood and subjectivism through a journey that configures engagement with cultures across national borders, but impedes successful maturation of the individual. This article contributes to a significant but still evolving strand of Modernist Studies, one that incorporates innovative narrative practices in Spanish fiction of the period, and locates these strategies within widereaching socio-cultural discourses of modernity in early twentieth-century Europe. My comparative analysis of cross-cultural echoes in the two novels under scrutiny seeks to extend 
recent academic approaches to Modernist prose fiction in Spain that reframe the fiction of Baroja and contemporaneous authors in a European literary context. The comparison focuses on three key strands. Firstly, I address the original publication of both novels in serial form and the presence of Conrad's novels in Baroja's library. Secondly, the article outlines the search for self-definition set against competing readings of each protagonist by multiple observers. Finally, by exploring a shared focus on the paralysis of psychological growth evidenced by each protagonist's failed attempts at heroism, I contend that the thwarted development of each individual references the modernising impulse of turn-of-the-century Europe.

Conrad's Lord Jim and Baroja's César o nada each deploys its protagonist to emphasise a cult of individualism in order to expose it. In this sense, both Conrad and Baroja demonstrate an ironic approach to the legacy of aestheticism, decadence and the heroic individual. Decadence valued transnational travel and awareness within its exposition of national culture. ${ }^{1}$ The appropriation and transformation of elements of Otherness were deemed necessary for the development of the individual, echoing the rite of passage of the Grand Tour. By contrast, both Lord Jim and César o nada ultimately undermine heroic appropriation through the crushing failure of the anti-hero. This element of each text exemplifies the difficulty of belonging, both within national cultural production (Conrad as the Polish émigré in Britain; the Basque roots of Baroja) and for the individual. The constitution of the autonomous subject was a cornerstone of Modernism, one that is problematized by the two texts under scrutiny. The accounts of otherness in César o nada, as in Lord Jim, are dependent on the failure to develop authentic selfhood, a resistance to appropriation that strikingly demonstrates Baroja's participation in transnational Modernist cultural endeavours of the early twentieth century.

\footnotetext{
${ }^{1}$ Rebecca L. Walkowitz, Cosmopolitan Style: Modernism Beyond the Nation (New York: Columbia University Press, 2006), 12 and Ana Parejo Vadillo, 'Cosmopolitan Aestheticism: The Affective "Italian” Ethics of A. Mary F. Robinson', Comparative Critical Studies 10:2 (2013), 163-82 (pp. 164-65).
} 
The comparative analysis of Baroja and Conrad undertaken by this study demonstrates compelling parallels between literary texts that renegotiate dominant assumptions regarding geographical hierarchies and the cultural production of the European periphery. These complex and varied interactions between cultures deserve further scrutiny for what they might tell us about diversity and interconnections in the development of literary Modernism across borders in turn-of-the-century Europe. If Lord Jim explores the legacy of cowardice through multiple subjective perspectives, César o nada explores a parallel dilemma of personality and competing identities embodied by Baroja's eponymous anti-hero. The psychology of cowardice in Lord Jim anticipates the psychology of inaction of César Moncada. In the former, Jim's character is placed in doubt through his exclusion from potential status as 'one of us' in relation to class, national identity and profession. His thwarted development references ironically the narratives of progress of European colonialism. For César, by contrast, selfhood is falsely dependent on the appropriation of an historical role model, one that fails to provide the necessary strength to foster self-definition through bourgeois masculine action in the political sphere. In Baroja's novel, Renaissance Italy offers through the model of the Borgia family an example of individual strength and energy that proves insufficient for overcoming aboulia and degeneration in early twentieth-century Spain, thereby providing an inadequate model for Spanish modernisation.

Spain's key participation in the trajectory of European Modernism is a phenomenon that scholarship has begun to tackle in earnest over the last two decades. The critical revision of Spanish literary history and Modernism has gained significant ground within an evolving body of research that together formulates the compelling argument that Spanish cultural figures made a significant, but often overlooked, contribution to Modernist literary history. ${ }^{2}$ This revisionist

\footnotetext{
${ }^{2}$ Key volumes include Modernism and Its Margins: Reinscribing Cultural Modernity from Spain and Latin America, ed. Anthony L. Geist and José B. Monleón (New York: Garland, 1999); ‘Hispanic Modernisms’, ed. Nelson R. Orringer, Bulletin of Spanish Studies, 79 (2002) 2-3: 133-409; the inclusion of Spain (albeit as a peripheral nation) in the updated edition of The
} 
perspective provides a re-evaluation of dominant Anglo-American critical narratives of Modernism and the long-standing exclusion of Spain from standard scholarly geographies of early twentieth-century European literature. I employ the term Modernism to denote the transnational artistic movements of the late nineteenth and early twentieth centuries that challenged, yet grew out of, the foundations of Realism. It thereby includes - but is not limited to - the Hispanic term modernismo, which connotes the legacy of Latin American poets José Martí and Rubén Darío from the 1880s onwards. Over the last twenty years, a number of volumes produced by British and North American Hispanism have aimed to re-situate Spanish writers of the early twentieth century, notably Antonio Machado, Pío Baroja, Miguel de Unamuno and Ramón Pérez de Ayala, in the context of European Modernism and cultural history. ${ }^{3}$ Gayle Rogers' Modernism and the New Spain remaps the relationship between Spain and Britain during the interwar period, with a particular focus on the Spanish avant-garde in the 1920s and 1930s. ${ }^{4}$ Other recent volumes include C.A. Longhurst's Modernismo,

Cambridge Companion to European Modernism, ed. Pericles Lewis (Cambridge University Press, 2014).

${ }^{3}$ See, for example, Roberta Johnson, Gender and Nation in the Spanish Modernist Novel (Nashville: Vanderbilt University Press, 2003); C.A. Longhurst, 'Coming in from the Cold: Spain, Modernism and the Novel', Bulletin of Spanish Studies 79 (2002): 263-283; Katharine Murphy, Re-reading Pío Baroja and English Literature (Oxford: Peter Lang, 2004); C.

Christopher Soufas, The Subject in Question: Early Contemporary Spanish Literature and Modernism (Washington DC: The Catholic University of America Press, 2007).

${ }^{4}$ Gayle Rogers, Modernism and the New Spain: Britain, Cosmopolitan Europe, and Literary History (Oxford University Press, 2012). 
noventayochismo y novela and Leslie J. Harkema's Spanish Modernism and the Poetics of Youth $^{5}$

As critics have pointed out, Spain had long been virtually excluded from the landmark scholarly volumes on European Modernism. ${ }^{6}$ Anglophone Modernist scholarship remains dominated by a widespread attachment to a centre-versus-periphery model, one that places 'core' nations such as France, Britain and Germany at the heart of cultural responses to social and technological modernity. These include the aesthetic innovation and rupture characteristic of Modernism across the spectrum of the arts, including literature, painting and music. For the nations of the periphery including both Southern and Eastern Europe, by contrast, Modernism has been commonly viewed not as the product but instead the route towards modernisation. In the case of Spain, the famous representatives of modern visual art such as Picasso, Joan Miró, Salvador Dalí and Juan Gris have been feted as key figures in the development of Modernism, Cubism, Surrealism and the avant-garde.

The Spanish novel, conversely, has been subject to a more problematic role in cultural accounts. Traditionally excluded from the seminal histories of European Modernism, early twentieth-century Spanish fiction was long studied in isolation from the aesthetic developments of other European nations, a position only encouraged by the insular notion of the 'Generation of $1898^{\prime}$. However, the view that Spain offers a striking contribution to the development of Modernism due to her unique path towards modernity in the early decades of the twentieth century is gaining persuasive ground. This critical reframing of Modernism emphasises, above all, its diversity in relation to artistic categories and genres, gender and geographies. Existing

\footnotetext{
${ }^{5}$ C.A. Longhurst, Modernismo, noventayochismo y novela: España y Europa (Bern: Peter Lang, 2014); Leslie J. Harkema, Spanish Modernism and the Poetics of Youth: From Miguel de
} Unamuno to La Joven Literatura (University of Toronto Press, 2017).

${ }^{6}$ Exemplified by Malcolm Bradbury and James McFarlane, eds., Modernism: A Guide to European Literature 1890-1930 (New York: Penguin, 1976). 
scholarly models that rest on the assumption of hierarchies and directional influence, from the core to the periphery, have been contested by more recent approaches, such as centrifugal versus centripetal migration. ${ }^{7}$

I seek to extend this evolving scholarship by exploring a cross-cultural paradigm that emphasises similarities in the literary expression of paralysed models of selfhood and failed individualism in early twentieth-century Britain and Spain. My article focuses on the influential figure of Joseph Conrad, the Polish émigré in Britain, a number of whose works appeared in Spanish translation in the 1920s. Baroja's library contains several volumes by Conrad, raising the pertinent question of direct influence particularly in relation to an ironic re-working of nineteenth-century novels of development in the representation of physical and psychological journeys. Both Baroja and Conrad question traditional expectations of the bildungsroman through the representation of stasis: the failed growth of the protagonist and its symbolic reference to broader socio-political metaphors of progress. In this context my article seeks to map literary echoes in the representation of selfhood in two well-known authors writing in Spain and Britain according to a fluid model of cultural exchange, interconnections and dialogue across borders. This case study thereby endorses the view that Spain may be reframed as a key site of transformation in the renegotiation of identity and subjectivity that underpinned the transition to Modernism in the European novel.

Alongside this argument, one must of course acknowledge the valuable work carried out by scholars of Spanish Realist fiction to problematize any straightforward trajectory between nineteenth-century fiction and its legacy for Modernism. Jo Labanyi contends that the self-referential questioning of representation in the Realist novel anticipates early twentieth-

\footnotetext{
${ }^{7}$ Pericles Lewis, Introduction, The Cambridge Companion to European Modernism (2014), 110 (p. 6). In her book Trafficking Knowledge in Early Twentieth-Century Spain: Centres of Exchange and Cultural Imaginaries (Woodbridge: Boydell and Brewer, 2009), Alison Sinclair analyses cultural networks across European borders.
} 
century cultural Modernism, and is particularly pertinent to our understanding of Spain's uneven development towards modernity. ${ }^{8}$ Her research underscores the preoccupation in the works of Leopoldo Alas and Benito Pérez Galdós with the limits of novelistic form and language itself. It is by now widely accepted that Modernism did not constitute a radical break with Realism (the aesthetics of rupture), but instead developed and intensified the questioning of representation already present in Realist novels, an argument that is acutely relevant in the case of Spain. The novels of Alas, Galdós and Emilia Pardo Bazán are thereby placed in continuum with the 'impressionism of Baroja and Azorín or the fictional games of Unamuno'. The focus of the present article on Modernist subjectivity does not intend to diminish the powerful legacy of nineteenth-century Realism and Naturalism for Baroja and his contemporaries. Literary precedents in Spain for Baroja's César o nada include Galdós’ El doctor Centeno (1883), which likewise may be categorised as a failed bildungsroman. At the same time, the long-standing critical view that Baroja was an outmoded traditionalist who demonstrated carelessness towards evolving questions of narrative form, subjectivity and representation at the turn of the twentieth century must similarly be challenged. ${ }^{10}$

In Britain, Conrad's decision to write in English was a source of suspicion but paradoxically also provided the seeds of his growing identity as a quintessentially British author. Baroja was certainly familiar with the works of Joseph Conrad and other authors of the period who lived and wrote in Britain; yet he has more frequently been compared with Charles

\footnotetext{
${ }^{8}$ Jo Labanyi, 'Modernity as Representation: The Self-Reflexivity of the Spanish Realist Novel', Romance Studies 30 (2012) 3-4: 238-43. For an extended account of the representation of contemporary life in late nineteenth-century fiction, see Labanyi, Gender and Modernization in the Spanish Realist Novel (Oxford: Oxford University Press, 2000).

${ }^{9}$ Labanyi, Gender and Modernization, 388, 398.

${ }^{10}$ Murphy, Re-reading Pío Baroja, 11-16.
} 
Dickens than with contemporaneous writers. ${ }^{11}$ My analysis, by contrast, reinforces the interpretation of Baroja not as an anachronistic adherent to earlier literary forms, but instead as a transitional figure in the development of Modernist narrative. I turn now to my first key area of analysis: the question of Conrad's potential influence on Baroja.

\section{Conrad's Works in Baroja's Library}

Joseph Conrad's novels enjoyed a prominent position in Baroja's personal library which is conserved at his house 'Itzea', Vera de Bidasoa (Navarra). Baroja was a well-known fan of Anglophone literature, and collected a wide range of novels by Dickens, Robert Louis Stevenson and Conrad among other authors. The publication dates for the editions of Conrad's novels collected in Baroja's library range from 1908 to 1926, reflecting his interest during this period in the Polish author. By the 1920s Spanish translations of Conrad's fictional works began to be published. Set on the Basque coast during the War of Independence, 'Inn of the Two Witches' (1913) was Conrad's first work to be translated into Spanish, and appeared with the title La posada de las dos brujas in 1925. Under Western Eyes (1911) was published as Alma rusa also in 1925. Spanish translations of Conrad's 'An Outpost of Progress', 'The Brute', and 'Gaspar Ruiz' also emerged in the mid-1920s.

Baroja was well-acquainted with the works of Joseph Conrad. There are seven novels by Conrad in his library at 'Itzea', some in English, some in French translation. In order of publication date, they are: A Set of Six (Leipzig: Bernhard Tauchnitz, 1908), Le Nègre du "Narcise” (Paris: Mercure de France, 1910), L'Agent secret (Paris: Mercure de France, 1912), La Folie Almayer (Paris: Editions de la Nouvelle Revue Française, 1919), Nostromo (Paris: Librairie Gallimard, 1926), The Nigger of the "Narcissus". A Tale of the Sea (Leipzig: Bernhard Tauchnitz, 1928), and L'Aventure (Paris: Simon Kra Editeur, 1926). They do not

\footnotetext{
${ }^{11}$ For example, Lourdes Lecuona Lerchundi, Presencia de lo inglés en Pío Baroja (DonostiaSan Sebastián: Fundación Social y Cultural Kutxa, 1993).
} 
include Lord Jim, although Baroja may well have been familiar with this work. The French translation of Lord Jim by Philippe Neel (Paris: Nouvelle Revue Française) first appeared in 1921, over a decade after the publication of César o nada. Other writers of adventure novels in his library include: Stevenson (17 titles), Kipling (15), Rider Haggard (11), Poe (8), Wilkie Collins (4). ${ }^{12}$ Baroja openly acknowledged his literary debt to the Anglophone adventure novel. ${ }^{13}$ Certainly, the emphasis on subjectivism and rendering point of view in Baroja's early novels points to his interest in the seafaring narratives of Conrad and Stevenson, both of whom have been recuperated as key figures in the emergence of European literary Modernism.

Conrad's novels started to appear in Spanish translation after his death in August 1924, coinciding with a documented period of cultural exchange between intellectual circles in Spain and Britain. Founded in 1923, the literary journal Revista de Occidente played a key role in Ortega y Gasset's regenerative project of Europeanisation which turned during the 1920s towards an emphasis on British models. During this period the Revista became increasingly interested in British and Irish authors, including James Joyce, Virginia Woolf, D. H. Lawrence and Aldous Huxley. As Rogers explains in his recent book, Ortega and his contemporaries sought to foster a cosmopolitan, intellectual platform through the publication of periodicals and translations of foreign works to encourage cultural exchange and collaboration across national borders. ${ }^{14}$ Joseph Conrad's death prompted a memorial, published by the Revista in 1924, in which Antonio Marichalar commented on the Anglo-Polish author's peripatetic journey towards 'Englishness'. In the memorial, Conrad is described as 'el antiguo expatriado polaco' who brought to English literature 'un elemento exótico de inapreciable valor: el genio de la raza

\footnotetext{
${ }^{12}$ Lecuona Lerchundi, Presencia de lo inglés, 248. On Baroja's library, the reader is referred to José Alberich, 'La biblioteca de Baroja', Revista Hispánica Moderna, 27:2 (1961), 101-12.

${ }^{13}$ Baroja, Obras completas, 8 vols (Madrid: Biblioteca Nueva, 1946-51), VII, 799.

${ }^{14}$ Rogers, Modernism and the New Spain, 3-4.
} 
eslava', through a Slavic combination of psychological and narrative complexity. ${ }^{15}$ In the internationalist context of the Revista, Marichalar presents Conrad's integration in England and Western Europe as a valuable means of incorporation of the exotic Eastern Other. As a Polish author writing in English, his third language, Conrad holds a particularly complex position with regard to the cultural periphery.

Existing scholarship has framed Conrad both as the quintessential British Modernist and a cosmopolitan par excellence. In early twentieth-century Britain, popular responses to Conrad's early publications demonstrate a problematic appeal to both nativist and international affiliations. Edward Garnett, who supported the publication of Conrad's first story, was a patron of international artists. In fact, Garnett's emphasis on the Polish author's ability to convey the 'secrets of Slav thought' through his use of the English language - 'our tongue' - in a review of The Secret Agent in 1907 betrays a curious entanglement of cultural assumptions. ${ }^{16}$ In the first decade of the twentieth century in Britain, the cosmopolitan identity acquired by Conrad drew primarily on his appropriation of the English language. This linguistic borrowing bestowed on him the concept of an invented self and simultaneously the failure in the eyes of contemporary reviewers to achieve natural expression. In 1908 Robert Lynd exposed Conrad's problem as a lack of 'concentration and intensity of vision' that is conferred by one's 'own language'. ${ }^{17}$ Conrad's Polish origins would lead to criticism of his unnatural attitude towards the English

\footnotetext{
${ }^{15}$ Antonio Marichalar, 'Estela de Joseph Conrad', in Ensayos Literarios, intro. and ed. Domingo Ródenas de Moya (Santander: Fundación Santander Central Hispano, 2002), 219-20 (p. 219).

${ }^{16}$ Edward Garnett, review of Joseph Conrad, The Secret Agent in Nation (28 September 1907), reproduced in Conrad: The Critical Heritage, ed. Norman Sherry (London: Routledge, 1973), 191-93.
}

${ }^{17}$ Robert Lynd, review, in Daily News (10 August 1908). Reproduced in Sherry, Conrad, 21012. 
language and culture, but paradoxically also to his subsequent position in literary history as an exemplary British novelist of the early twentieth century. In her study of the myriad crossings between cosmopolitanism and Modernism, Walkowitz defines Conrad as 'at once the most British and the most cosmopolitan of novelists'. ${ }^{18}$

Lord Jim and César o nada each represents the protagonist according to competing perspectives on the part of other characters who observe and interpret the eponymous antiheroes. Alongside these thematic comparisons, however, the structure of both novels was also dependent on the demands of serial publication. In 1898 Conrad began 'Tuan Jim: A Sketch', originally intended to be a short story of 20,000 words which eventually grew into Lord Jim. The initial draft occupied twenty-eight pages of an album in which Conrad's maternal grandmother had transcribed several Polish poems. This draft would form the basis for the initial chapters of Lord Jim, the writing of which produced numerous revisions between the periodical version and the first English edition. From four instalments the novel increased to 120,000 words in fourteen instalments. ${ }^{19}$ Lord Jim appeared in serialised form in Blackwood's Edinburgh Magazine (Maga) between October 1899 and November 1900, and was published as a book in 1900 both by Doubleday (New York) and by Blackwood (Edinburgh and London). Lord Jim therefore became extensively longer than the original commission for a short story, to be published in a volume alongside 'Youth' and Heart of Darkness, three narratives connected by the interpretative role of Marlow. However, the most substantial revisions are found between the periodical and the first English edition (of 1900), evidence that Conrad substantially changed his conception of the novel after it had already begun to appear in Blackwood's

\footnotetext{
${ }^{18}$ Walkowitz, Cosmopolitan Style, 30, 35.

${ }^{19}$ Thomas C. Moser, ed., 'Textual History', in Joseph Conrad, Lord Jim (New York: Norton, 1996): 247-51 (p. 249).
} 
Magazine. The most radical modifications relate to Jim's psychology, which Conrad decided was too explicit in the periodical version. ${ }^{20}$

A contemporary review of Lord Jim praised the vividness and complexity of narration as a 'delicate piece of mosaic, of which each of the myriad tiny fragments that compose it is essential to the whole'. ${ }^{21}$ It is common knowledge that Conrad's financial affairs were in dire straits, and he was obliged to work on a number of works simultaneously in order to pay his debts. During the composition of Lord Jim he also wrote 'Youth' (1898), Heart of Darkness (1899), and continued his troubled work on The Rescue (1920). As he wrote to William Blackwood in February 1900, he was unwell with malaria, bronchitis and gout as he continued to write further instalments of Lord Jim, which he completed in July 1900.

Baroja's César o nada was likewise serialised prior to publication as a book, appearing in instalments in the Republican daily newspaper El Radical between 6 March and 26 May 1910. Shortly afterwards it was released in volume form with Biblioteca Renacimiento. In $E l$ Radical the work was published in 67 instalments, which bear no relation to the twenty-one chapters. There were in fact two versions of the first edition of César o nada. One version includes an additional, final chapter (XXII), ironically entitled 'Finis Gloriae Mundi', in which César is revealed to be a bourgeois art collector rather than a man of action, and declares pragmatically that 'yo no soy nada, nada'.22 Standard versions of the novel omit the additional chapter, thereby maintaining a less explicit stance in relation to the fundamentally sceptical approach to César's characterisation by not revealing what happens to the protagonist after he

\footnotetext{
${ }^{20}$ Moser, 'Textual History', 249.

${ }^{21}$ Hugh Clifford, 'The Genius of Mr Conrad', in Conrad, Lord Jim, 396.

${ }^{22}$ Baroja, César o nada (Madrid: Espasa-Calpe, 1934), 360. All subsequent references are to this edition.
} 
has been wounded by gunshot, or even whether he lives or dies. ${ }^{23}$ This final chapter provides a scathing assessment of the protagonist who is finally exposed as a failure, a perspective missing from the ambivalent ending of post-1934 editions.

The author's own visits to Rome between 1906 and 1909 provided inspiration for the fictional travelogue of Part I of César o nada. The lengthy trip to Rome functions as psychological preparation for César's political ambitions in Spain. Set in Italy, Part I is often accused of being repetitive and prolix, in comparison with the economy of Part II in Spain. This echoes in reverse the charges against the structure of Lord Jim: the structural simplicity of the Patna sequence, followed by the prolix Part II in Patusan. In each case the two-phase plot demonstrated by César o nada and Lord Jim emphasises the refusal of both novels to trace successful growth towards defined selfhood and heroic qualities. Likewise, for each author, the demands of serial publication helped to shape narrative form that in turn underpins the antihero's frustrated development through the emphasis on external perception. In each novel a series of embedded narrators provide competing perspectives on the protagonist, as narrative viewpoints prioritise observation and reflection over meaningful action in the thwarted idealism of César and Jim.

\section{Defining Selfhood}

The memorable opening section of Conrad's Lord Jim is broadly familiar in English literary scholarship. The novel's protagonist Jim is a young first mate on the merchant ship Patna. As he dreams of heroic adventure, 'saving people from sinking ships, cutting away masts in a hurricane, $[\ldots]$ as unflinching as a hero in a book', the Patna encounters an unknown

\footnotetext{
${ }^{23}$ See C.A. Longhurst, 'Ironic distance in Baroja: César o nada', Bulletin of Hispanic Studies, 57 (1980): 129-42 (p. 135).
} 
obstacle, lists and appears to be at the point of sinking. ${ }^{24}$ Jim escapes the Patna on the lifeboat, leaving eight hundred passengers on board. Following 'Youth' and Heart of Darkness, Lord Jim is one of three tales that Conrad published between 1898 and 1900 in which the narrator Marlow sets out to interpret the facts and central characters. Each of these tales addresses different forms of failed idealism. In Lord Jim Marlow and his listeners (an audience of seafarers) must each weigh up numerous competing perspectives within the composite impression of Jim, a process that echoes the Court Inquiry that investigates the actions of the central character on the night of the incident on board the Patna.

Conrad's protagonist is represented through layers of subjective interpretation within Marlow's narrative, which draws on a number of interactions with key witnesses of Jim's subsequent experiences. The paradoxical nature of identity is summed up nowhere more clearly than in the novel's title: the ironic discrepancy between the grandeur of 'Lord' and the modest nickname Jim. Eventually through Marlow's intervention the protagonist is removed by the trader Stein to Patusan, the colonial outpost in Borneo where Jim will attempt but fail to redeem himself. In Patusan, Jim assumes the identity of an idolised leader: the parson's son is caught in an illusion of pseudo-aristocracy. His attempted rehabilitation in this remote district of Malaysia is the basis for his newly wrought identity as Tuan Jim or local deity: here he demonstrates 'intellectual alertness', 'readiness', 'dignity' and 'high seriousness' (226), a display of personal 'gifts' (226) that initially appear to impress Marlow. However, Jim's imagined heroics are undermined by the lowly banality of his actions, a discrepancy that betrays his inflated egoism both on the beleaguered Patna and as Tuan Jim in Patusan.

Following the treachery of Cornelius and the massacre by Gentleman Brown's men, Doramin (Chief of the Bugis) kills Jim beside the body of his dead son Dain Waris. Conrad's protagonist remains unforgiven, a victim to the last of his 'exalted egoism' (351). Jim's sudden

\footnotetext{
${ }^{24}$ Joseph Conrad, Lord Jim, intro. and ed. Cedric Watts (Harmondsworth: Penguin, 1989), 47. All subsequent references are to this edition.
} 
death reveals the inability to overcome the dominance of ego and the perpetual youth that embodies the fantasy of his romantic illusions and those of European colonialism. In Conrad's Lord Jim, the encounter with the Other draws on competing legends: the heroic identity to which Jim aspires, which is undermined by his jump from the Patna, and the subsequent 'Jimmyth' constructed by the Malay community of Patusan. In César o nada cross-cultural encounters are located within Europe, according to the protagonist's search for a well-defined identity, one inspired by the Italian Renaissance and specifically the figure of Cesare Borgia. In each case, the heroism of the individual is sustained by historiographical discourses that transform fact into myths and legends. ${ }^{25}$ It is worth noting that Baroja had already satirised European colonialism in an earlier novel Paradox, Rey (1906), in which the eponymous figure is a type of comic Tuan Jim.

In Conrad's Lord Jim selfhood is both relative and infinite, as the protagonist negotiates a range of fantasised identities set against the reality of his cowardly action in jumping from the Patna. In César o nada, by contrast, the trope of subjective perception is overtly posed in terms of duality: the protagonist may be defined as César or as nothing. César himself affirms that if he succeeds, he will be viewed as 'una gran figura', but if he fails he will be remembered as 'un canalla, $[\ldots]$ un bandido (17). However, despite the dual implications of the novel's title, over the course of the narrative César's actions are explained by a range of different observers, suggesting that the process of interpretation moves beyond polarised possibilities. Therefore as Longhurst notes in his analysis of ironic distance in César o nada, 'the central problem in this novel is the same as that in, let us say, Conrad's Lord Jim: the impossibility of arriving at the

\footnotetext{
${ }^{25}$ On historical references in Baroja's novel there are two pertinent articles by David Henn: 'History, Philosophy, and Fiction: Pío Baroja's César o nada', Neophilologus 87 (2003): 23346 and 'Baroja's César o nada and Other Evocations of Cesare Borgia in Spanish Literature of the 1890s and Early 1900s', Romance Studies 25 (2007) 1: 3-14.
} 
true nature or character of the protagonist' ${ }^{26}$ A detailed comparative study of the two novels has yet to be undertaken, a scholarly gap that my article attempts to address. Furthermore, the expression of national traditions is contested by each writer's experience of Otherness, whether European (the model provided by Renaissance Italy in Baroja) or global (colonialism in Conrad). In each case, early twentieth-century narratives of progress and modernisation are assessed in response to the geographical site of the protagonist's attempted leadership (the provincial Castilian town of Castro Duro in César o nada; the colonial outpost Patusan in Lord Jim), as both César and Jim become symbols of failed individualism.

In Baroja's César o nada the regenerationist search for national identity is echoed by the entrenched problem of self-definition and emotional growth embodied by its protagonist, César Moncada. His search for selfhood takes place first through the contact with Italy provided by the travelogue in Part One, ideas that he subsequently implements through his career in local politics in provincial Spain in Part Two. The novel thus employs a widespread fin-de-siècle trope in which travel to Italy as the Southern European Other would commonly be expected to foment change, intellectual growth, and cultural maturity. Arriving in Rome after a long journey, he is tired, weak and feverish, as his sister Laura notes: ‘¿Y tú llamas acción a estar tendido en la cama leyendo?' (54). By contrast with his plans for decisive action in the financial and political sphere, César finds himself devoid of energy, suffering bouts of melancholy when Laura takes a trip to Florence. In place of emotional growth and self-definition, the prolix Part One in Rome exposes a paralysis of action and emotional stasis that subverts the linear development of selfhood of a conventional journey narrative.

In Baroja's representation of Italy as exotic Other there are numerous contradictory echoes of decadent fiction of the period. The exotic appeal of Italy that is manifest in César o

\footnotetext{
${ }^{26}$ Longhurst, 'Ironic distance', 130-31. The point that Jim's enigmatic personality cannot be explained, and provides a parallel with Baroja's characterisation of César, is restated briefly in Longhurst's more recent study Modernismo, noventayochismo y novela (78).
} 
nada has much in common with British authors of the period such as E.M. Forster, who sends his sheltered, upper middle-class characters to Italy as a catalyst for spiritual growth in the cultured landscapes of Florence and Rome. Baroja's use of the trope, however, is fundamentally ironic: César attempts to apply the worldly knowledge he has gained in Italy, but later fails to recognise the futility of his political activity in Castro Duro. The figure of Cesare Borgia as a ruthless political model that functions as an alter-ego for Baroja's protagonist in César o nada was likewise a common feature of British decadent authors of the period. The primacy of the individual and his creation through contact with foreign models of individualism proffered by Italian history and the Borgia family appears frequently in the Cosmopolitan Aestheticism of authors such as Henry James, Vernon Lee, A. Mary F. Robinson and Oscar Wilde. ${ }^{27}$ By contrast, Baroja echoes but mockingly reframes a journey characteristic of the fin de siècle. César Moncada searches for self-definition through identification with the exotic Other, a process purportedly fostered by his examination of Renaissance Italy, but one that is doomed ultimately to disappointment.

Upon arrival in Italy Baroja's protagonist defines himself in relation to the condottiero Cesare Borgia, the illegitimate son of Pope Alexander VI, and a figure notorious for his ruthlessness and political ambition in Renaissance Italy. ${ }^{28}$ César is drawn magnetically to this historical namesake: 'Ya tenía César Moncada una gran curiosidad. Estos Borgia le interesaban. Su simpatía iba hacia aquellos grandes bandoleros que dominaban Roma y querían apoderarse de Italia, penca a penca, como una alcachofa. Su propósito le parecía bien, casi moral. La divisa «Aut Caesar, aut nihil» era digna de un hombre de genio y de valor' (175). The youthful qualities of Cesare Borgia are also emphasised by Kennedy's historical explanation, providing

\footnotetext{
${ }^{27}$ See Parejo Vadillo, ‘Cosmopolitan Aestheticism', 163-67.

${ }^{28}$ On cultural responses to this figure in the works of turn-of-the-century Spanish authors, including modernista poets and Ramón del Valle-Inclán's Sonatas, see Henn, 'Baroja’s César o nada and Other Evocations of Cesare Borgia', 4-6.
} 
an implicit counterpoint with César's fatigue: at the age of twenty he was 'fuerte, ágil, domaba caballos, manejaba las armas admirablemente y mataba toros' (175). Baroja's protagonist expresses moral approbation for the figures who privileged energy and power above political or social integrity. Narrative irony is abundantly apparent in the doubling of protagonist and alterego, a statesman and mercenary who was ambushed in battle, and whose remains were expelled from Church burial. The notorious outcome of Cesare Borgia's exploits provide a mocking foil for his weak-willed double in César o nada.

In any case, heroic legend provides a flawed foundation for the protagonist's selfdefeating construction of identity in Baroja's novel. He claims in a letter to his friend Alzugaray that in Spain 'somos individualistas; por eso, más que una organización democrática, federalista, necesitamos una disciplina férrea, de militares' (180). The falsity of this political philosophy will be drawn out once César implements his leadership in Castro Duro in Part Two. The novel has sometimes been read as a call for the military discipline of a tyrant, in the light of the protagonist's statement that 'lo único que nos convendría es tener un jefe ... para tener el gusto de devorarlo' (180). ${ }^{29}$ It should be remembered, however, that these are the words of the character and not the author. It is misleading to assume that César's political beliefs were shared indiscriminately by Baroja; the ideological distance between author and protagonist is demonstrated not least by the scepticism towards César's ideas expressed by a number of characters and by the doctor-figure of the prologue.

The title of both novels introduces from the outset competing readings of each protagonist. Conrad's anti-hero is represented through a range of masculine viewpoints, including Marlow, the trader and collector of butterflies Stein, the adventurer Brown, and 'the privileged man': the only listener to whom Marlow sends the end of Jim's story. As Marlow acknowledges, 'I don't pretend I understood him. The views he let me have of himself were like

\footnotetext{
${ }^{29}$ Jo Labanyi, Myth and History in the Contemporary Spanish Novel (Cambridge University Press, 1989), 60.
} 
those glimpses through the shifting rents in a thick fog, [...] Upon the whole he was misleading' (99). Even Jim's own account of himself is 'overwhelmed by the inexplicable' (294). By contrast, Stein diagnoses the protagonist's predicament in simple terms: 'He is romantic' (199). Jewel's stepfather, Cornelius, is similarly concise; describing Jim as 'just like a fool. [...] He is like a little child' (322-23) he echoes the trope of perilous immaturity that defines the protagonist throughout the novel. Gentleman Brown is initially puzzled, then draws on 'an assumption of common experience; a sickening suggestion of common guilt' (329), thereby manipulating the protagonist to collude in his own downfall through the insinuation of shared dishonour. Jim releases Brown and his men from Patusan, a judgement that leads to ambush and the death of Dain Waris, the catalyst for his own demise.

Baroja's César is defined by the competing comments of both male and female observers including his sister Laura, lovers Condesa Brenda and Susana Marchmont, his future wife Amparito, friends Ignacio Alzugaray and Kennedy, and the priest Padre Martín. The exploration of selfhood thereby draws on the subjective interpretation of a number of interlocutors as César's personality remains elusive and opaque. Early in the novel Laura describes her brother's rejection of the Church's teachings about human compassion as 'ideas más feas' (13). Furthermore, she undercuts his theories of morality and leadership as 'pretensiones [...] tontas' (18), instead calling him 'bambino' (18). This term of affection, repeatedly employed by Laura during their visit to Rome, closely recalls the infantile status of Jim explored above.

The ironic referencing of César's immaturity continues at the hotel. Condesa Brenda draws attention to his air of exhaustion and likens him to an anaemic girl, thereby effeminizing him in the process: ‘ $¡$ Pobrecito! Me da usted pena. ... ¡Porque es usted tan débil, tiene usted un aire tan grande de agotamiento! ¿Qué hace usted para estar así? Debe usted necesitar que le den algún jarabe ferruginoso como a las niñas anémicas' (96-97). César conceives himself as the Nietzschean man of action, but is characterised by others as lacking strength, masculinity and voluntad. César is an abúlico: he lacks willpower, and is defined by racial weakness and 
exhaustion. Later he accepts the advances of the wealthy married American Susana Marchmont due to his own 'inercia' (203). Condesa Brenda's infantilisation of César above emphasises his failure to progress towards moral growth and maturity, an observation that places serious doubt over his future capacity for leadership and political action in Castro Duro. As in the case of Jim, César is caught in a cycle of perpetual youth, unable to achieve wisdom or progress, a trope that has striking implications for the representation of national symbols.

Compounding these obstacles to personal development, César's downfall (like Jim's) is spurred by egoism. His programme of social reform draws on the desire for political power, although he claims humanitarian ambitions. As he explains to the local priest Padre Martín, he wishes to bring an end to 'la anarquía que reina en Castro y someterla a un pensamiento, a un pensamiento digno y noble' (341) and aims to achieve this through 'el derecho de ser el más fuerte' (341). Backing the forces of tradition and Catholicism, the priest tellingly terms his adversary's form of proposed leadership as 'una dictadura revolucionaria' (343). Indeed, as Longhurst reminds us, the falangista writer Giménez Caballero claimed that Baroja had created César Moncada in the image of a fascist leader. ${ }^{30}$ In this context, the protagonist becomes a failed echo of the authoritarian iron surgeon recommended by the famous lawyer and regenerationist Joaquín Costa as the cure for Spain's ills. The author strongly objected to these claims, stating that his intention was to present César's political views, not to defend them $(O C$, VII, 741).

A proclaimed strength of ego provides the foundations for César's development of his own often opportunistic expression of a political philosophy. Yet, following financial machinations on the stock-market in Paris, inspired by his interpretation of Cesare Borgia's exploits in Senigallia, César becomes exhausted and feverish, and spends two days recovering in bed. Beneath his confident exterior lurk doubts and fears, as he confesses when confronted by political challenges in Castro Duro: 'dudaba de sí mismo, empezaba a creer que no era el héroe'

\footnotetext{
${ }^{30}$ Longhurst, 'Ironic distance in Baroja, 131-32.
} 
(323). The protagonist's attempts to define a strong leadership role are repeatedly undercut by multiple subjective observers, at times by the narrative voice, and by his own struggle with despondency and fatigue, all of which together expose his inability to live up to the ego-ideal he has sought to establish. César emerges not as a ruthless despot but instead as an aesthete whose sister has married into aristocracy, and who by the end of the novel lives in comfort and relative wealth with his wife Amparito, a vivacious 'señorita rica' (316).

In Conrad's novel, Marlow represents a mature counterfoil to Jim's youthful fervour. Despite this, Lord Jim carefully casts doubt on the authority of Marlow, whose own romantic idealism leads to false belief in the golden-haired boy, and exposes a deep ambivalence and selfdoubt towards his own interpretative role. Marlow represents the contradictions in the colonial drive for endless modernisation, rather than detached neutrality. In César o nada, Baroja's narrative form carefully integrates a range of interlocutors who comment on and often challenge César's actions and self-beliefs, spurring further displays of bravado. This provision of counterpoints to his protagonist's goals rests on an ironic narrative presentation of César's ambitions for rural and political modernisation through the brutal strength of masculine action.

Baroja's own protagonist is introduced as a young man - 'un joven flaco, rasurado, grave, taciturno' (10) - whose ideas are set against those of the thinly veiled author-figure of the prologue. The latter appears in the guise of the doctor of Cestona, where Baroja practised medicine briefly in 1894 . This semi-autobiographical character converses with César, a narrative strategy that imposes differences in viewpoint between author and protagonist. The doctor, for example, disagrees with César's definition of morality, arguing instead that from his point of view 'la idea de moral va más bien vinculada a la idea de piedad que a la idea de energía' (15). This passage provides a veiled reference to the philosophies of Schopenhauer (as represented by the doctor) and Nietzsche (as represented by César). I have already noted that Conrad's use of Marlow creates ambivalence about the central character. The presence of the 'médico de Cestona' in César o nada creates a similar type of uncertainty, since it raises the possibility that he is the author of the fictional biography of César Moncada which he has 
written to combat 'la vida monótona del pueblo' (18), the closing words of the prologue. This detail adds to the indeterminacy of César's character: the protagonist is imagined by a third party who admired him yet dissented from his ideological position.

At recurrent points in the novel, Baroja's protagonist expounds his inconsistent political philosophy to his friend Ignacio Alzugaray, who provides a sceptical sounding-board for César's ideas and a counterpoint to his political idealism. Attending school in Madrid, César looks thin and sickly, and becomes an object of ridicule among his fellow students for wrapping himself in paper to avoid catching cold. Alzugaray abstains from expressing direct agreement or disagreement towards the protagonist's developing philosophy of action, but perceives clearly that his friend's ideas 'no ofrecían nada práctico' (47). In the early sections of the novel, César's radical defence of changing ideological positions is repeatedly undercut. The narrator informs us that he is a mediocre pupil; his fellow students avoid debating with a boy who claims to have 'el monopolio de la verdad' (41). Later Alzugaray will interpret César's bullying tactics in Castro Duro as 'una política bárbara' (307). In other words, a range of perspectives are employed to cast doubt over the protagonist's self-image and highlight the obstacles in his unsuccessful journey towards authentic self-definition.

At times the narrator exposes the flaws in the protagonist's plans for the future. In Rome, for example, 'César reconocía en su fuero interno que no tenía plan ni la menor orientación' (69). The priest Preciozi is unsure whether to read his friend as 'un inocente' or 'un hombre maquiavélico' (70); Cardinal Fort provides only a frosty reception for his nephew, believing he is 'un incrédulo' (82). The ladies at the hotel are unsure whether to interpret him as a womanising Don Juan, 'una hiena' (87) who breaks hearts, or a financier in the making. Señorita Cadet reads his hand, surmising a mass of contradictions - he is 'bueno y malo, $[\ldots]$ muy valiente y muy cobarde' (107); however, she states with certainty that he lacks 'voluntad'. The young English diplomat Kennedy expresses the opinion that his friend pretends to be 'tranquilo y equilibrado', but in fact is 'un ergotista' (132) and 'un satírico completo' (134); Laura adds affectionately that he is a demagogue. Overall all these opinions point to a 
performance of personality undertaken by César in Rome, beneath which his true substance has yet to be discovered.

\section{Failed Heroism and Ironic Narratives of Progress}

As Part Two of César o nada progresses, the protagonist's political leadership is revealed to be both idealistic and egotistical. Once he moves in to Don Calixto's house, the former 'palacio de los duques' in Castro Duro, César is dubbed by the narrator a 'cacique bueno' (310); his political leadership can best be defined as a benign form of paternalism. At this point, he defines himself to his future wife as a neurasthenic: 'Soy un hombre enfermizo, con el espíritu ulcerado, llagado...' (313). Far from being spurred on by the emotional energy of Amparito, his marriage leads instead to disengagement from his vision for rural Castile just as major political disturbances challenge the strength of his leadership. Reneging on his political promises, he flees to Italy to avoid the trial of Juan 'el Babas', perceiving that 'ya no tengo energía, ya no tengo dureza' (332), and declares himself too unwell to return to Castro Duro. As the looming elections draw near, primitive violence amongst political factions accompanies electoral falsification in the region.

In the town's isolation from the outside world of progress and modernity, the setting becomes an enclosed sphere of inaction that returns to both tradition and primitivism. Sketched by impressionist narrative upon César's first visit, Castro is finally the site of Baroja's mordant irony regarding the entrenched influence of the forces of Catholicism and tradition. By the end of the novel Castro Duro has returned to order and conservativism, without water or irrigation, the school has been closed and workers' rights suppressed, and the inhabitants are emigrating in their droves: 'Castro Duro sigue viviendo con sus veneradas tradiciones y sus sacrosantos prinicipios, sin permitir que los advenedizos sin religión y sin patria turben su vida’ (359).

The ending of Baroja's novel emphasises the ironic undermining of Cesar's selfperception. When he returns to Spain and runs once again for municipal councillor in the local elections, this time representing the liberals, he proclaims that: 'Soy un hombre fuerte, soy un 
hombre de hierro; para mí ya no hay obstáculos. Las fuerzas de la naturaleza me ayudarán. ¡César! He de ser César’ (353). But far from being invincible, the protagonist is seriously injured by a gunshot. The electoral proceedings are falsified by the supporters of his (now) conservative opponent, who wins the elections. Baroja documents the development of his antihero, but refuses to classify or pretend to explain him. From the outset the author advises the reader that the individual cannot be fully understood: 'Lo individual es inagrupable e inclasificable. Lo individual no puede en absoluto entrar de lleno en un encasillado’ (8). Unlike Jim, César survives and retires from the political sphere, at any rate in the original edition. As noted above, this ending is missing in the Obras completas and other subsequent versions, which present an entirely uncertain conclusion.

Conrad famously quipped that in his case 'homo duplex' had more than one meaning. ${ }^{31}$ In Lord Jim, Marlow's account of Jim assesses the communication and transmission of our perceptions (visual, ethical, social) of ourselves and others. Above all, Conrad's novel famously explores the nature and multiplicity of selfhood, the idea 'that we contain more potential lives than real life permits us to realise'. ${ }^{32}$ The repeated trope that Jim is 'one of us' highlights the dilemma of identity and psychic identification: the implication of each and every reader in the narration of Jim's act of cowardice. The moral identity of Conrad's protagonist is hidden by false projected versions of selfhood and romantic idealism that impede psychological growth and lead instead to emotional stasis.

It has been acknowledged by recent criticism that Lord Jim is structured by reference to 'the world of adventure' (24), according to which Jim constructs his identity from 'a course of light holiday literature' (47). The experience of maritime life in the first part of the novel

\footnotetext{
${ }^{31}$ The Collected Letters of Joseph Conrad: Volume 3, 1903-1907, ed. Frederick R. Karl and Laurence Davies (Cambridge University Press, 1988), xxiii.

${ }^{32}$ Cedric Watts, Introduction, Lord Jim, 11.
} 
incrementally subverts his romantic expectations. ${ }^{33}$ Following the Court Inquiry, the protagonist sets out on an endless journey of shame in every port to which he travels. In Part Two, the romance of Patusan is already an impossibility. ${ }^{34}$ This systematic challenge to the romantic adventure novel provides a rich foundation for Lord Jim. As Andrea White observes, Conrad's novels of empire conform to elements of the adventure genre but simultaneously subvert traditional assumptions of this type of fiction. His works thus provide a counterpoint to the imperialist adventure genre of authors such as Robert Louis Stevenson and Rudyard Kipling, in novels that privilege male heroism, strength and courage. Adventure fiction 'traditionally celebrated an unqualified kind of heroism', thereby sustaining 'the energizing myth of English imperialism, ${ }^{35}$ In Lord Jim, by contrast, the protagonist's reveries are undercut through the discrepancy between aspiration and action, a process that finds parallels in César's false identification with the Borgia dynasty in Baroja's novel of 1910.

Subjectivity is rendered as a disjunction between elusive and multiple truths and the distraction of illusion. The insistent verbal leitmotif that Jim was 'one of us' refers variously to his position in relation to race (a white man), class (a gentleman), gender, and belonging (a seaman). It also indicates his human frailty in relation to the Fall from Grace, from innocence to moral knowledge. Jim inspires false confidence through his childlike appearance and attributes. He is repeatedly referenced as boyish in appearance, with 'clear blue eyes' (125) and fair hair. Thus Marlow asserts that in Patusan he would see Jim 'loved, trusted, admired, with a legend of strength and prowess forming round his name as though he had been the stuff of hero' (171).

\footnotetext{
${ }^{33}$ See Robert Hampson, Cross-Cultural Encounters in Joseph Conrad's Malay fiction (Basingstoke: Palgrave, 2000), 129.

${ }^{34}$ Chris Bongie, Exotic Memories: Literature, Colonialism, and the Fin de Siècle (Stanford: Stanford University Press, 1991), 176.

${ }^{35}$ Andrea White, Joseph Conrad and the Adventure Tradition: Constructing and Deconstructing the Imperial Subject (Cambridge University Press, 1993), 5-6.
} 
Conrad's language is carefully couched through conditional structures: Jim has the potential for heroism, but ultimately fails to bring that possibility to fruition. In Patusan, Jim constructs the illusion of supernatural powers. Confronted by a potentially hostile environment, he acquires a dual identity, wrought through bold self-reinvention and the construction of an audacious illusion sustained above the threat of self-knowledge. Jim's identity remains impenetrable, as Marlow observes: 'you shall always remain for them an insoluble mystery' (269).

Jim's name acquires heroic associations through the transformation of material facts by the community of Patusan. This transmission of legend conveys the protagonist with supernatural powers, the 'Jim-myth' (250) that competes with Marlow's own account of his personality and identity. As Marlow concludes, each of us must interpret 'for himself' the 'language of facts' (293), yet facts are 'more enigmatic than the craftiest arrangement of words' (293). Hampson argues that through the arrangement of competing accounts, which provide a demonstration of the transmission of legend and myth, Lord Jim reproduces the 'ideologicallyloaded discourse of $[\ldots]$ historiographic tradition' ${ }^{36}$ The Patusan sequence references the activity of seventeenth-century traders, the Dutch and English adventurers who had a 'passion for pepper' (209). The task of commerce is then overwritten by a nineteenth-century perspective of heroism and adventure, in which 'they appear magnified, not as agents of trade but as instruments of a recorded destiny, pushing out into the unknown' (210). The factual and the legendary are thereby conflated in the history of European voyages to Patusan, foreshadowing the competing accounts of Jim's powerful ascent in the region. ${ }^{37}$ Marlow, of course, claims a privileged perspective and authority in his own rendering of Jim. The 'Jim-myth' created by the local people of Patusan, however, is one example of the transmission of communal narratives, just as we must interpret subjectively also the dissemination of rumour and gossip about Jim among the European accounts of the colonial community in Part One.

\footnotetext{
${ }^{36}$ Hampson, Cross-Cultural Encounters, 139.

${ }^{37}$ Hampson, Cross-Cultural Encounters, 139-40.
} 
By the end of the novel, Jim remains 'under a cloud' (350), and he surrenders his life to atone for his errors in judgement and moral dishonour. His character remains oblique and impossible to render clearly. As Marlow asserts, 'he made so much of his disgrace while it is the guilt alone that matters. He was not - if I may say so - clear to me. He was not clear. And there was the suspicion he was not clear to himself either' (173). The authority of narrative interpretation is ultimately a futile goal. At the heart of Marlow's tale is an obvious emphasis on solipsism, human isolation and the difficulty of understanding fully oneself or others. Neither Jim nor César emerges as the hero envisioned in his illusions and dreamt self-image. Marlow transforms Jim from a marginalised outcast to apparently 'one of us', but fails ultimately to redeem him. At the end of each novel, neither César nor Jim is rehabilitated. Each protagonist is defeated by an ideological construction of heroism, as fantasised narratives (the appeal of legend and projected identity) obscure an elusive truth. For the protagonist of César o nada, as in Lord Jim, the allure of myth, legend and ideological discourse overwrites the facts. Furthermore, what appear to be the distinguishing characteristics of self and other that are divided by the distance of time and place are ultimately conflated. Heroism is therefore exposed as a contradictory cultural narrative that is interpreted through ideological discourse and the process of historiography.

In a recent book, Esty contends that the Modernist exploration of progress in Anglophone fiction was often underpinned by disruptions to the conventions of the nineteenthcentury bildungsroman, instead positing youth as a site of failed development and progress. The novels of youth of Conrad and other authors of this period thereby trace the uneven trajectory of selfhood in parallel to developmental discourses of nation and empire. ${ }^{38}$ Whilst the bildungsroman traditionally measured the cumulative development of character through a narrative of education, by contrast both Jim and César neglect to acquire knowledge that is

\footnotetext{
${ }^{38}$ Joshua Esty, Unseasonable Youth: Modernism, Colonialism, and the Fiction of Development (New York: Oxford University Press, 2012).
} 
sufficient to dent their idealism and the strength of ego that lies beneath the failures of each protagonist. Conrad's Jim is characterised repeatedly as the fair-haired boy who fails to integrate knowledge in the wake of his disgrace when he jumped from the Patna. This rejection of narratives of growth is underlined by Marlow's observation that Jim is 'the youngest human being now in existence' (204). Condemned to perpetual youth and passivity, Jim's predicament becomes part of a wider symbolic commentary about what Esty terms the tension between the ethos of modernisation and the uneven development of the colonial periphery. ${ }^{39}$ In Baroja's novel, by contrast, César's thwarted search for self-definition highlights the national context of regenerationism in early twentieth-century Spain. As the weak-willed, racially exhausted antihero, Moncada becomes a symbol and heir of degeneration and national decline: an emblem of unsuccessful growth in the light of Spain's uneven progress towards modernity. Like Jim, however, César struggles against stasis and passivity in his attempt to rewrite an elusive identity through action.

In Castro Duro, César sets out on a programme of socio-political reform in a rural context. This includes the aim to oust the caciques, reduce the power of the Church by re-establishing instead a Centro Obrero, and improve local services and infrastructure, including irrigation, roads, and education. To some extent, the changes sought by César echo the Manifiesto de los Tres, the 1901 regenerationist statement of Azorín, Maeztu and Baroja. Although the manifesto clearly reverberates with contemporaneous regenerationist reform in Spain, put forward ambitiously by Joaquín Costa among others, in fact the developments called for in the Manifiesto de los Tres were limited to the appeal to tackle poverty, prostitution and alcoholism, to address the need for education, economic support for agriculture, and the implementation of divorce. ${ }^{40}$

\footnotetext{
${ }^{39}$ Esty, Unseasonable Youth, 72.

${ }^{40}$ Luis S. Granjel, Panorama de la generación del 98 (Madrid: Guadarrama, 1959), 220-23.
} 
César's own activity focuses predominantly on the lack of progress and modernisation of rural Spain due to the corruption of political systems. Although he is a young man, the protagonist lacks sufficient energy to overcome the force of existing historical explanations of national decline. Harkema argues that the early twentieth-century fascination with adolescence provided a potential antidote to narratives of imperial decline and Spanish belatedness, by subverting positivist notions of progress. ${ }^{41}$ In the late nineteenth century, as 'technological and scientific progress began to acquire connotations of decadence, artists and writers viewed Western civilisation itself as ossified and senile'. In this European context, turn-of-the-century Spanish regeneracionismo becomes 'a commentary on the history of ageing itself' that echoes cultural discourses of decline and stagnation. ${ }^{42}$ The relatively linear development of César from immaturity, through initial successes in the financial and political spheres, to retirement from political life in the bourgeois role of an art collector is profoundly ironic. Through its scepticism towards false narratives of progress and modernisation, César o nada draws on and intensifies the development of the individual embodied in (but often problematized by) the nineteenthcentury bildungsroman and Spanish Realist fiction. In doing so, the novel emphasises the fragmentation of personality and insoluble ambiguities of character comparable to those explored by Lord Jim and other Modernist representations of selfhood.

$* * *$

Baroja's rendering of the fractured subject in César o nada accompanies the fictional developments in early twentieth-century Spain towards an incipient literary Modernism. The comparison with Conrad's Lord Jim acknowledges differences in the treatment of failed narratives of progress: the emphasis on colonialism in Conrad as opposed to national regenerationism in Baroja. Nonetheless, the two novels reveal significant points of comparison in relation to thwarted journeys of development. In each case, the encounter with other cultures

\footnotetext{
${ }^{41}$ Harkema, Spanish Modernism and the Poetics of Youth, 5.

${ }^{42}$ Harkema, Spanish Modernism and the Poetics of Youth, 8.
} 
resists an outcome of psychological and emotional growth for the protagonist. In both novels, the individual's failed idealism questions linear narratives of development and refuses to create a defined subjectivity.

As in the case of Jim, the geographical site of César's illusions exposes both his moral and professional failure, as dreams of heroism become divorced from the realities of action. Jim cannot be redeemed by return to England, and dies in Patusan. César returns from Italy, but fails in provincial Castile to implement his goals. The trajectory of Jim and that of César each reveals a fantasy of moral integrity in a new environment ruled by the character's leadership, a dream rendered impossible by his symbolic lack of maturation. Each moves from idealism to the sudden curtailment of action, through the death of Jim and the shooting of César. In the latter case, political idealism leads not to death but instead bourgeois passivity in the additional final chapter, and a denial of resolution in subsequent editions. In different ways, both novels reject the closure of psychological growth and maturity. My article has explored evidence that supports the likely influence of Conrad's literary works on Baroja, given the Anglo-Polish writer's popularity in the library at 'Itzea'. The comparative exploration of anti-heroism and impeded narratives of development in César o nada and Lord Jim extends growing arguments for the recognition of the significant contribution made by early twentieth-century Spanish authors to the development of European Modernist narrative fiction. 